\title{
Standardization of an Effective Protocol for in vitro Culture of Lilium longiflorum Thunb cv. Pavia
}

\author{
N.S. Bhandari ${ }^{1}$ and C. Aswath ${ }^{2}$ \\ ${ }^{1}$ Division of Ornamental Crops, ICAR - Indian Agricultural Research Institute, \\ New Delhi, India \\ ${ }^{2}$ Division of Floriculture and Medicinal Crops, ICAR-Indian Institute of Horticultural \\ Research, Bangalore, Karnataka, India \\ *Corresponding author
}

\section{A B S T R A C T}

\section{Keywords}

Lilium longiflorum, Sterilants, Explants, in vitro culture, Bulblets induction

Article Info

Accepted:

10 March 2018

Available Online:

10 April 2018
The present study was carried out to develop an effective protocol for in vitro culture of Lilium longiflorum T. cv. Pavia. Three different types of explants like leaves, outer and inner bulb scales were exposed to two sterilants: sodium hypochlorite $(\mathrm{NaClO})$ and hydrogen peroxide $\left(\mathrm{H}_{2} \mathrm{O}_{2}\right)$ with their varying concentrations; $\mathrm{NaClO}(2 \%, 3 \%, 4 \%$ and $5 \%)$ and $\mathrm{H}_{2} \mathrm{O}_{2}(0.05 \%, 0.10 \%, 0.15 \%$ and $0.20 \%)$. Among all treatments, $\mathrm{NaClO} @ 3 \%$ was highly effective over different regime of $\mathrm{H}_{2} \mathrm{O}_{2}$ for minimizing contamination $(18.66 \%)$, low necrosis $(2.67 \%)$ and maximum survivability $(79.13 \%)$. Highest bulblets induction (4.66) and maximum bulblets diameter $(7.85 \mathrm{~mm})$ was recorded in Murashige and Skoog (MS) medium supplemented with BAP $(0.5 \mathrm{mg} / \mathrm{l})$ and NAA $(0.3 \mathrm{mg} / \mathrm{l})$. The maximum length of shoots $(38.33 \mathrm{~mm})$ and fresh weight $(239.51 \mathrm{mg})$ were recorded with BAP $(1.0 \mathrm{mg} / \mathrm{l})$ and NAA $(0.1 \mathrm{mg} / \mathrm{l})$. The maximum numbers of basal roots $(5.83$ /bulblets) were obtained with $0.3 \mathrm{mg} / \mathrm{l} \mathrm{NAA}$. The maximum length $(49.00 \mathrm{~mm})$ of basal roots was recorded with BAP $(1.0 \mathrm{mg} / \mathrm{l})$ and NAA $(0.3 \mathrm{mg} / \mathrm{l})$. This protocol is highly useful for mass multiplication of true-to-type, disease free planting material of lilium.

\section{Introduction}

The genus Lilium comprises more than 100 geophytes of family Liliaceae, are economically important ornamental plant grown throughout the world (Xia et al., 2006). Lilium holds $4^{\text {th }}$ position among top 10 cut flowers in world floriculture trade (Bhandari $e t$ al., 2016). Among Indian growers lilies are the most popular because of their wider adaptability, ease of growing, high ornamental value, high rehydration capacity after prolonged transportation, long vase life of the cut flowers in water and high cost benefit ratio (Pandey et al., 2009). Slow multiplication rate in conventional method is the main constraints in commercial expansion of these species. In vitro micropropagation provides an alternative for the rapid propagation of lilies (Nhut et al., 2001). In recent years, the tissue culture has proven to be most efficient for the mass propagation and multiplication of Lilium genus, as it helps in producing high quality plants (Kanchanapoom et al., 2011), and in 
maintaining germplasm of endangered and endemic species (Skoric et al., 2014). Bulb scales are the most widely used explants for lilium in vitro culture (Pandey et al., 2009). As the bulblets regenerate from bulbs within 8-10 weeks, individual scales of bulblets, or parts thereof, can be used for further propagation. Consequently, with the help of tissue culture, about a million bulblets can be obtained from a large bulb (14-16 cm in circumferences) in 2 years. Nevertheless, from a commercial point of view, micropropagation proves to be the fastest and disease-free propagation method for Lilium. Conversely, till date, very less effort has been focused on micropropagation of lilium in India. Taking this into consideration, the present study has been taken up to investigate and standardize an efficient protocol that will provide a valuable basis for establishment of effective axenic cultures for in vitro propagation of lilium.

\section{Materials and Methods}

The present investigation was conducted in the Tissue Culture Laboratory, Division of Floriculture and Medicinal Plants, ICARIIHR, Karnataka, Bengaluru during 20162017. The experiment was designed based on Factorial CRD (completely randomized design) with 3 replications for each treatment and repeated twice. The explants used were outer and inner bulb scales and leaves from field grown lilium (cv. Pavia) plants and two sterilizing agents i.e., sodium hypochlorite $(\mathrm{NaClO})$ in the form of commercial bleach containing $5 \%$ active chlorine and nano embedded hydrogen peroxide $\left(\mathrm{H}_{2} \mathrm{O}_{2}\right)$ with four varying concentrations and were tested with the three different explants. Autoclaved distilled water used as control. Initially explants were placed under running tap water to remove adhering dust particles. Subsequent surface sterilization was carried out inside laminar air flow. The explants were primarily treated with carbendazim $(0.2 \%$ for 30 minutes) followed by ethanol $70 \%$ for $1 \mathrm{~min}$ and three wash with sterile water. Later explants were subjected to different concentration of two sterilants containing 2 drops of Tween 20 per liter for 15 minutes. Each sterilization step was followed by 3 washes with autoclaved sterile distilled water to remove the traces of chemicals. Explant sections $10 \mathrm{~mm}$ were obtained by transversally slicing the bulb scales and leaves with four explants inoculated in each culture bottle containing $50 \mathrm{ml}$ of MS media (autoclaved) supplemented with varying concentrations of BAP:NAA, placed in growth chamber maintained at $24 \pm 1{ }^{\circ} \mathrm{C}$ temperature and $16 / 8$ $\mathrm{hr}$ illumination (light/dark period) provided by cool-white fluorescent lamps. Observations were recorded on contamination (\%), necrosis $(\%)$, and survival (\%). As well the data on growth parameters, viz., number of bulblets formed per explants, shoot length, shoot diameter, root length $(\mathrm{cm})$ and bulblets fresh weight (average) were recorded after 8 weeks of culturing. Eventually, the recorded data was statistically analyzed with the help of ANOVA using online OPSTAT (Statistics Analytical Software) developed by department of computer section, CCSHAU, Hisar, Haryana.

\section{Results and Discussion}

Surface sterilization of explant is a pre requisite for the establishment of aseptic invitro culture, as the culture medium favors the growth of both explants and microbes. To achieve suitable sterilizing of explants and successful culture, lilium explants (leaves, outer and inner bulb scale) were subjected to two sterilants $\left(\mathrm{NaClO}\right.$ and $\left.\mathrm{H}_{2} \mathrm{O}_{2}\right)$ with different sterilization regimes using $\mathrm{MS}$ (Murashige and Skoog, 1962) as the inoculation medium. The effects of surface sterilizing treatments on aseptic culture establishment of different explants are presented in Table 1. Contrary to the result on 
contaminated cultures, highest contamination $(93.33 \%)$ was observed when no sterilants were used $\left(\mathrm{T}_{1}\right)$. Pre sterilizing treatment $\mathrm{T}_{5}$ (NaOCl@ 5\%) was the best over other treatments in minimizing the contamination $15.34 \%, 11.33 \%$ and $12.34 \%$ with outer and inner bulb scales and leaves respectively. However, $\mathrm{T}_{9} \quad\left(\mathrm{H}_{2} \mathrm{O}_{2} @ 0.20 \%\right)$ treatment reduced contamination upto $17.67 \%, 13.34 \%$ and $15.33 \%$ with outer and inner bulb scales and leaves, that was significantly on par with $\mathrm{T}_{5}$. Treating the lilium bulb's inner scale with $\mathrm{NaClO}(5 \%)$ and $\mathrm{H}_{2} \mathrm{O}_{2} \quad(0.20 \%)$ resulted significantly less contamination as compare to other treatments. However, among both sterilants $\mathrm{NaClO}$ found superior over $\mathrm{H}_{2} \mathrm{O}_{2}$ to reduce the contamination across all three explants (Fig. 1). The interaction effect between different sterilant concentrations over all explants were found significant. These results are in close compliance with the reports of Palei et al., (2017) in Lilium regale. As in the case of Lilium explants (scales), which are bulbs grown under the soil; hence, harboring an elevated number of potentially harmful contaminants is currently leading to losses ranging from 20 to $80 \%$.

It was evident that the sterilant concentration and exposure time had a strong effect on explants necrosis and survival. Increasing the sterilant concentration and exposure time more than optimum gives a negative effect on survivability of explants because of its bleaching or phyto-toxic effects. The presented data in Table 1 and Figure 1 showed that explants necrosis was increased as the concentration of both sterilant raised. The maximum necrosis $(65.00 \%, 64.66 \%$ and $58.67 \%$ ) was recorded with inner scale, leaves and outer scales when treated with $\mathrm{T}_{9}$ $\left(\mathrm{H}_{2} \mathrm{O}_{2} \quad 0.20 \%\right)$, that was significantly higher than $\mathrm{T}_{5}, \mathrm{~T}_{8}$, and $\mathrm{T}_{4}$. Consequently at low level of sterilant concentration (Fig. 1), the high level of contamination was observed with minimum necrosis $1.78 \%\left(\mathrm{~T}_{3}\right)$ and $2.75\left(\mathrm{~T}_{7}\right)$.
In contrast, $\mathrm{T}_{9}$ pre-sterilizing treatment showed the maximum percentage of explants necrosis (62.94). Results of these finding explains necrosis of explants is directly proportional to sterilants concentration. This can be attributed to the obliteration of explants tissue due to the phytotoxic effect of sterilants at high concentration (Pandey et al., 2009). Generally, explants are sensitive to sterilant concentration especially at higher level. In fact it has been observed the death of surface layers of explants by high concentration of sterilants (Pierik, 1987).

Table 1 enumerate that among all the explants culture establishments, inner scale gave highest survival $(79.13 \%)$ when treated with $\mathrm{T}_{3}(\mathrm{NaOCl} 3 \%)$ as it favored less necrosis $(2.67 \%)$ and less contamination $(18.66 \%)$ as compare to others and followed by $\mathrm{T}_{7}$ and $\mathrm{T}_{4}$. The same trends of survivability were recorded in outer bulb scale and leaves with $\mathrm{T}_{3}$ treatments. As compared to control $\left(\mathrm{T}_{1}\right)$ other treatments had a significant effect on explants survival. Among different types of explants, inner scale explants showed higher survivability than outer scale and leaves. As the data presented in figure 1, a keen observation was recorded for maximum survival $(77.76 \%)$ when explants treated with $\mathrm{T}_{3}$ across all treatments and was followed by $\mathrm{T}_{7}(72.38 \%)$ that were significantly higher than other treatments. It was observed that explants survivability was increased as sterilants concentration raised only upto an optimum level and after that it reduced because, higher concentration lead to higher necrosis and phyto-toxicity (Fig. 1). These results are in close conformity with Jan et al., (2013). In addition, studies were conducted to initiate bulblets induction using best explant i.e., inner scales with best sterilant concentration (NaClO@ 3\%) to minimize contamination, increase survivability and culture establishment for in vitro propagation of L. longiflorum cv. Pavia. 
Table.1 Effect of sterilants on percent contamination, necrosis and survival of different explants of Lilium cv. Pavia

\begin{tabular}{|c|c|c|c|c|c|c|c|c|c|}
\hline \multirow[b]{2}{*}{ Treatments } & \multicolumn{3}{|c|}{ Contamination } & \multicolumn{3}{|c|}{ Necrosis } & \multicolumn{3}{|c|}{ Survival } \\
\hline & $\begin{array}{l}\text { Outer } \\
\text { Scale }\end{array}$ & $\begin{array}{l}\text { Inner } \\
\text { Scale }\end{array}$ & Leaves & $\begin{array}{l}\text { Outer } \\
\text { Scale }\end{array}$ & $\begin{array}{l}\text { Inner } \\
\text { Scale }\end{array}$ & Leaves & $\begin{array}{l}\text { Outer } \\
\text { Scale }\end{array}$ & $\begin{array}{l}\text { Inner } \\
\text { Scale }\end{array}$ & Leaves \\
\hline $\mathrm{T}_{1}$ : Control & 97.33 & 87.33 & 95.33 & 0.00 & 0.00 & 0.00 & 2.67 & 12.67 & 4.67 \\
\hline $\mathrm{T}_{2}: \mathrm{NaOCl} @ 2 \%$ & 56.34 & $43 . .34$ & 52.67 & 0.00 & 0.00 & 0.00 & 43.73 & 56.46 & 47.46 \\
\hline T3: NaOCl @3\% & 23.66 & 18.66 & 19.66 & 0.00 & 2.67 & 2.67 & 76.40 & 79.13 & 77.76 \\
\hline $\mathrm{T}_{4}: \mathrm{NaOCl} @ 4 \%$ & 19.60 & 16.66 & 17.33 & 17.66 & 26.33 & 22.66 & 62.66 & 56.97 & 60.00 \\
\hline $\mathrm{T}_{5}: \mathrm{NaOCl} @ 5 \%$ & 15.34 & 11.33 & 12.34 & 26.83 & 46.67 & 53.66 & 57.93 & 42.00 & 34.00 \\
\hline $\mathrm{T}_{6}: \mathrm{H}_{2} \mathrm{O}_{2} @ 0.05 \%$ & 62.67 & 50.67 & 59.34 & 0.00 & 0.00 & 0.00 & 37.46 & 49.66 & 40.00 \\
\hline $\mathrm{T}_{7}: \mathrm{H}_{2} \mathrm{O}_{2} @ 0.10 \%$ & 27.66 & 21.34 & 25.66 & 1.14 & 3.60 & 3.50 & 71.10 & 75.33 & 70.73 \\
\hline $\mathrm{T}_{8}: \mathrm{H}_{2} \mathrm{O}_{2} @ 0.15 \%$ & 22.34 & 19.67 & 19.66 & 25.66 & 32.73 & 28.60 & 52.20 & 47.66 & 51.80 \\
\hline $\mathrm{T}_{9}: \mathrm{H}_{2} \mathrm{O}_{2} @ 0.20 \%$ & 17.67 & 13.34 & 15.33 & 58.67 & 65.00 & 64.66 & 23.30 & 21.20 & 20.16 \\
\hline SEm & 1.621 & 1.254 & 1.457 & 0.242 & 0.283 & 0.233 & 0.431 & 0.682 & 0.462 \\
\hline CD@ 5\% & 4.813 & 3.746 & 4.361 & 0.725 & 0.848 & 0.697 & 1.291 & 2.31 & 1.384 \\
\hline
\end{tabular}

Table.2 Effect of BAP and NAA with MS media on in vitro induction and Proliferation of bulblets

\begin{tabular}{|c|c|c|c|c|c|c|c|}
\hline \multicolumn{2}{|c|}{$\begin{array}{l}\text { Plant growth } \\
\text { regulators } \\
(\mathrm{mg} / \mathrm{l})\end{array}$} & \multirow[t]{2}{*}{$\begin{array}{c}\text { No. of } \\
\text { bulblets/ } \\
\text { explant }\end{array}$} & \multirow{2}{*}{$\begin{array}{l}\text { Diameter } \\
\text { of } \\
\text { bulblets } \\
\text { (mm) }\end{array}$} & \multirow{2}{*}{$\begin{array}{l}\text { Length } \\
\text { of } \\
\text { shoots } \\
\text { (mm) }\end{array}$} & \multirow[t]{2}{*}{$\begin{array}{l}\text { No. of } \\
\text { roots/ } \\
\text { bulblets }\end{array}$} & \multirow{2}{*}{$\begin{array}{c}\text { Root } \\
\text { length/ } \\
\text { bulblets } \\
(\mathbf{m m})\end{array}$} & \multirow[t]{2}{*}{$\begin{array}{c}\text { Fresh } \\
\text { weight/bulblet } \\
\text { (mg) }\end{array}$} \\
\hline BAP & NAA & & & & & & \\
\hline 0.0 & 0.0 & 2.67 & 3.73 & 13.66 & 2.73 & 17.33 & 89.53 \\
\hline 0.0 & 0.1 & 3.33 & 5.42 & 16.34 & 3.51 & 28.66 & 107.21 \\
\hline 0.0 & 0.2 & 3.66 & 6.31 & 18.36 & 4.22 & 32.00 & 119.43 \\
\hline 0.0 & 0.3 & 3.99 & 6.93 & 21.66 & 5.83 & 35.33 & 135.51 \\
\hline 0.5 & 0.0 & 3.33 & 6.27 & 23.33 & 2.14 & 26.00 & 145.63 \\
\hline 0.5 & 0.1 & 3.66 & 6.45 & 25.00 & 2.85 & 31.33 & 162.21 \\
\hline 0.5 & 0.2 & 4.33 & 6.72 & 26.66 & 3.73 & 34.66 & 178.13 \\
\hline 0.5 & 0.3 & 4.66 & 7.85 & 27.33 & 4.64 & 35.66 & 195.52 \\
\hline 1.0 & 0.0 & 3.00 & 5.33 & 28.00 & 2.47 & 33.00 & 222.43 \\
\hline 1.0 & 0.1 & 3.66 & 6.76 & 38.33 & 2.93 & 37.66 & 239.51 \\
\hline 1.0 & 0.2 & 3.66 & 7.24 & 31.99 & 3.65 & 42.33 & 234.42 \\
\hline 1.0 & 0.3 & 3.33 & 6.56 & 29.66 & 4.16 & 49.00 & 219.46 \\
\hline \multicolumn{2}{|c|}{ SEm } & 0.333 & 0.010 & 0.333 & 0.481 & 0.373 & 0.491 \\
\hline \multicolumn{2}{|c|}{ CD@ 5\% } & 0.979 & 0.028 & 0.940 & 1.413 & 1.094 & 1.444 \\
\hline
\end{tabular}


Plate.1 Complete protocol of Lilium bulblets induction from inner scales

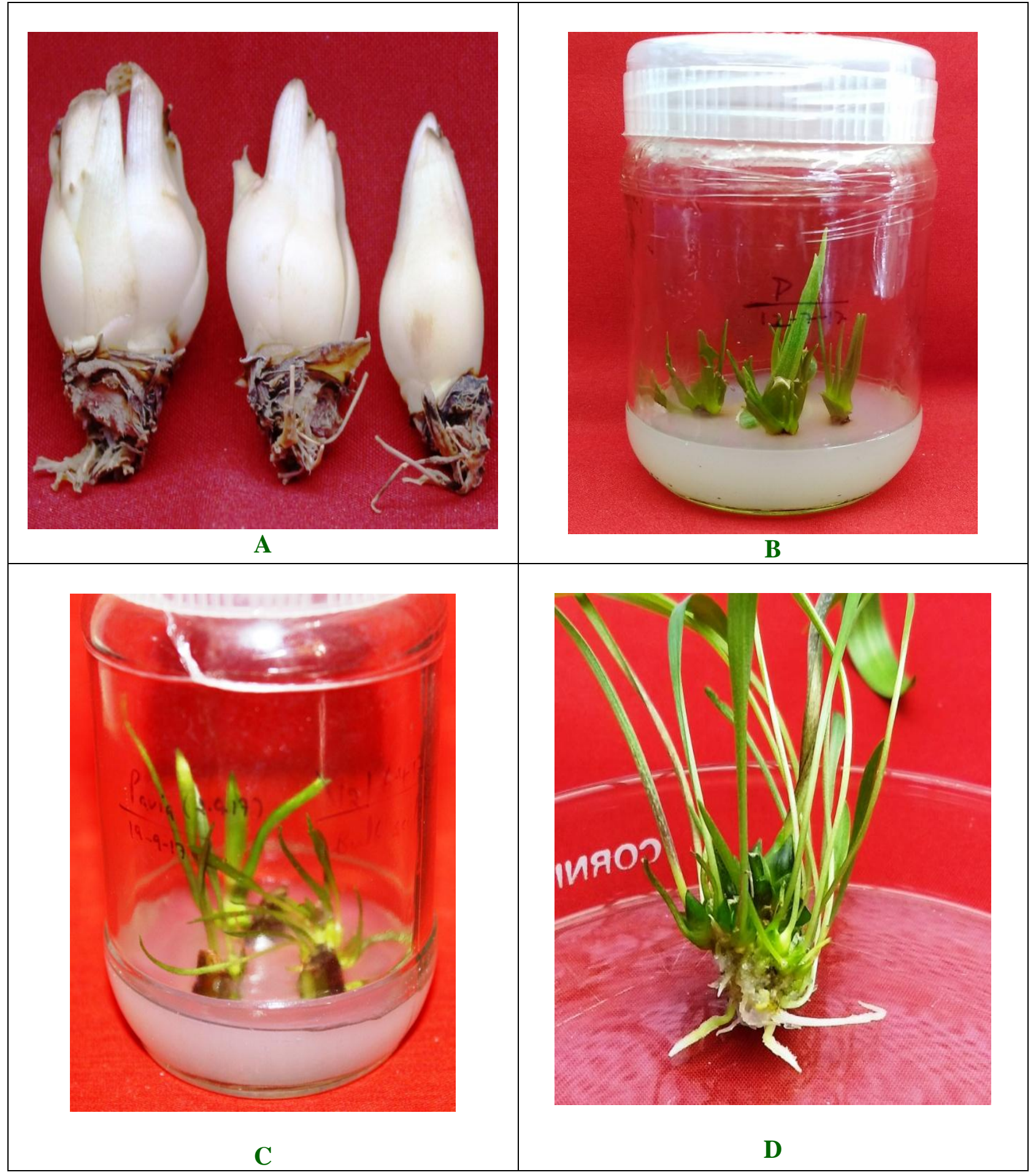

A: Lilium bulb's inner scales

B: 4 weeks cultured Lilium bulb's inner scale treated with $\mathrm{NaOCl} @$ 3\%

C: 8 weeks induced bulblets on BAP $(0.5 \mathrm{mg} / \mathrm{l})$ and NAA $(0.3 \mathrm{mg} / \mathrm{l})$

D: Shoot proliferation on BAP $(1.0 \mathrm{mg} / \mathrm{l})$ and NAA $(0.1 \mathrm{mg} / \mathrm{l})$ 
Fig.1 Interaction effect of sterilants concentration on percent contamination, necrosis and survival

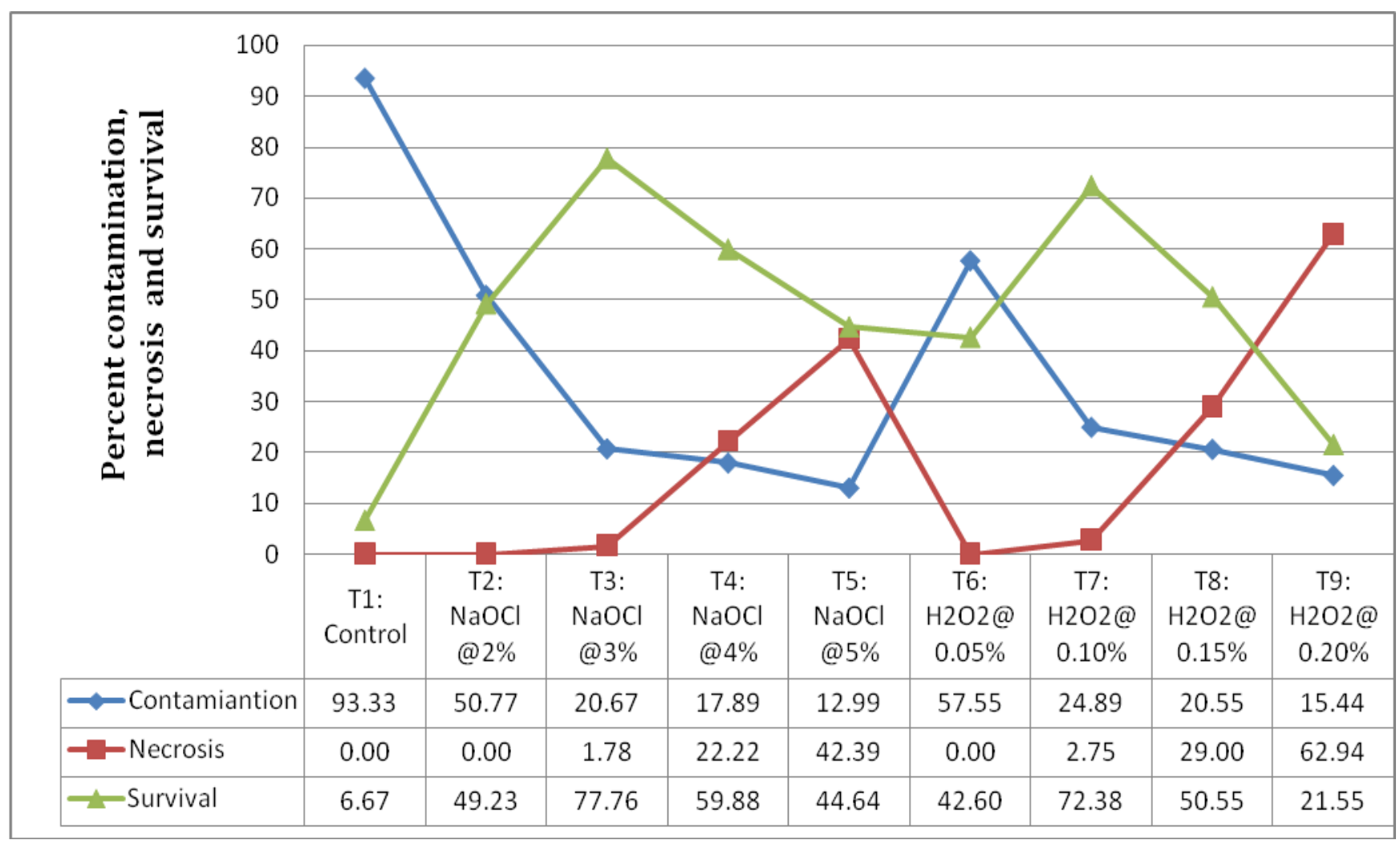

Perusal of data from Table 2 revealed that different BAP concentrations $(0,0.5$ and 1.0 $\mathrm{mg} / \mathrm{l})$ along with NAA $(0.1,0.2$ and $0.3 \mathrm{mg} / \mathrm{l})$ were tested for in vitro culture establishment. Under different growth regulators tested, the maximum number of bulblets 4.66 and 4.33 per scale were observed in MS medium supplemented with BAP $(0.5 \mathrm{mg} / \mathrm{L})+\mathrm{NAA}$ $(0.3 \mathrm{mg} / \mathrm{L})$ and BAP $(0.5 \mathrm{mg} / \mathrm{L})+\mathrm{NAA}(0.2$ $\mathrm{mg} / \mathrm{L})$ respectively that were significantly on par with each other and higher than the other treatments. This might be due to the fact that BAP: NAA promotes induction of daughter bulblets in excised organs and tissues. Likewise, Sivanesan et al., (2012) had observed in his studies that BA was found to be the most effective cytokinin for multiple shoot induction among the other cytokinins used and correspondingly, Nilmi (1984) had reported NAA was essential for the formation and growth of bulblets in the scale cultures.
Among the different phyto-hormones treatments, maximum diameter of bulblets $(7.85 \mathrm{~mm})$ was obtained with BAP $(0.5 \mathrm{mg} / \mathrm{L})$ + NAA $(0.3 \mathrm{mg} / \mathrm{L})$, which were significantly higher than others. Similarly, the highest shoot length $(38.33 \mathrm{~mm})$ and highest mean fresh weight $(239.51 \mathrm{mg}$ ) was observed on MS medium supplemented with BAP (1.0 $\mathrm{mg} / \mathrm{L})+$ NAA $(0.1 \mathrm{mg} / \mathrm{L})$. These results are also tantamount with findings of Kumar et al., (2008), recorded highest fresh weight (171.70 $\mathrm{mg}$ ) of in vitro root with $1.5 \mathrm{mg} / \mathrm{l} \mathrm{NAA}$ and $2.0 \mathrm{mg} / \mathrm{l} \mathrm{BA}$ in oriental hybrid cv. Marco Polo.

It is clearly evident from the Table 2 that, maximum number of roots (5.83) observed with MS medium supplemented with NAA $(0.3 \mathrm{mg} / \mathrm{l})$ that was significantly at par with 0.2 $\mathrm{mg} / \mathrm{l}$ NAA (4.22) and followed by $0.1 \mathrm{mg} / \mathrm{l}$ NAA (3.51) treatments. This might be due to 
the fact that NAA being an auxin promotes root formation and growth. These results are in accordance with the observation made by Maesato et al., (1991) in L. japonicum. Similarly, longest root length $(49.00 \mathrm{~mm})$ was obtained in MS medium supplemented with BAP $(1.0 \mathrm{mg} / \mathrm{L})+\mathrm{NAA}(0.3 \mathrm{mg} / \mathrm{L})$ that were significantly higher than BAP $(1.0 \mathrm{mg} / \mathrm{L})+$ NAA $(0.2 \mathrm{mg} / \mathrm{L})$ and BAP $(1.0 \mathrm{mg} / \mathrm{L})+\mathrm{NAA}$ $(0.1 \mathrm{mg} / \mathrm{L})$. The present findings lend support from the previous work done by Kawarabayashi and Asahira (1988), who reported the maximum number of roots and root length in MS medium supplemented with NAA in L. speciosum cv. Uchida.

Our research finding revealed sodium hypocholride has turned out to be better sterilants than $\mathrm{H}_{2} \mathrm{O}_{2}$ because available chlorine sterilized the explants effectively to reduce the chance of contamination. Among different concentration and exposure time of sterilants, $\mathrm{NaClO}(3 \%)$ treatment for 15 minutes was highly effective over different regime of $\mathrm{H}_{2} \mathrm{O}_{2}$ for minimizing contamination (18.66\%), low necrosis (2.67\%) and maximum survivability $(79.13 \%)$. Among the three explants; inner scales performed better than other explants across all growth parameters. With inner scales highest bulblets induction (4.66) and maximum bulblets diameter $(7.85 \mathrm{~mm})$ was recorded in Murashige and Skoog (MS) medium supplemented with BAP $(0.5 \mathrm{mg} / \mathrm{l})$ and NAA $(0.3 \mathrm{mg} / \mathrm{l})$. The maximum length of shoots $(38.33 \mathrm{~mm})$ and fresh weight $(239.51 \mathrm{mg})$ were recorded with BAP $(1.0 \mathrm{mg} / \mathrm{l})$ and NAA $(0.1 \mathrm{mg} / \mathrm{l})$. The maximum numbers of basal roots $(5.83$ /bulblets) were obtained with 0.3 $\mathrm{mg} / \mathrm{l}$ NAA. The maximum length $(49.00 \mathrm{~mm})$ of basal roots was recorded with BAP (1.0 $\mathrm{mg} / \mathrm{l})$ and NAA $(0.3 \mathrm{mg} / \mathrm{l})$. As a consequence, the present study demonstrates a simple and rapid yet efficient method for high frequency direct shoot regeneration from inner scales of Lilium cv. Pavia that would be advantageous for mass propagation and multiplication of such a valuable flower crop in India.

\section{References}

Bhandari, N.S., Srivastava, R. and Kumar, S. 2016. Effect of substrates on lilium (Lilium longiflorum L.) programming in container system. Indian J. Hort. 73(3): 456-459.

Jan, A., Bhat, K.M., Bhat, S.J.A., Mir, M.A., Bhat, M.A., Imtiyaz A. and Wani J.A. 2013. Surface sterilization method for reducing microbial contamination of field grown strawberry explants intended for in vitro culture. African $J$. Biotech. 12(39): 5749-5753.

Kanchanapoom, K., Ponpiboon, T., Wirakiat W. and Kanchanapoom, K. 2011. Regeneration of lily (Lilium longiflorum 'Easter lily') by callus derived from leaf explants cultured in vitro. Sci. Asia. 37: 373-376.

Kawarabayashi, W. and Asahira, T. 1988. Effect of different media and culture conditions on the growth of shoot tips of lilies cultured in vitro. J. Japanese Soc. Hort. Sci. 57: 258-68.

Kumar, S., Chaudhary, V. and Kanwar, J.K. 2008. In vitro propagation of oriental hybrid lily from root explant. $A d v$. in Hort.Sci. 22: 63-5.

Maesato, K.K., Sarma, S., Fulkuit, H. and Hara, T. 1991. In vitro bulblet induction from shoot apices of Lilium japonicum Thumb. Hort Sci. 26: 211-19.

Murashige, T., and Skoog, F. 1962. A revised medium for rapid growth and bioassays with tobacco tissue cultures. Physiologia Plantarum. 15: 473-497.

Nhut, D.T., Lee, B.V., Teixeira, D.A., Silva, J.A. and Aswath, C.R. 2001. Thin cell layer culture system in Lilium: Regeneration and transformation perspectives. In Vitro Cell. \& Dev. Bio. Plant. 37: 516-523. 
Nilimi, Y. 1984. Effect of NAA and BA on the development of excised bulblets of Lilium rubellum Baker, cultured in vitro. J. Japanese Soc. Hort. Sci. 53: 5965.

Palei, S., Das, A.K., Dash, D.K. and Rout, G.R. 2017. Effect of surface sterilant for reducing microbial contamination of field grown strawberry explants intended for in vitro culture. International Journal of Chemical Studies. 5(4): 1476-1479.

Pandey, R.K., Singh, A.K. and Sharma, M. 2009. In vitro propagation of lilium. Biologica forum-An int. J. 1(2): 20-22.

Pierik, R.I.M. 1987. In-vitro culture of higher plants. 3rd edition Dordirectit, Martinus Nishoff publishers, kluwer academic publishers groups.

Sivanesan, I., Lim, M.Y. and Jeong, B.R. 2012. Micropropagation and green house cultivation of scrophularia Takesimensisnakai, A rare endemic medicinal plant. Pak. J. Bot. 44(5): 1657-1662.

Skorić, M., Živković, S., Savić, J., Šiler, B., Sabovljević, A., Todorović, S., \& Grubišić, D. 2014. Efficient one-step tissue culture protocol for propagation of endemic plant, Lilium martagon var. cattaniae Vis. African J. of Biotech., 11(8):1862-1867.

Xia, Y., Deng, X., Zhou, P., Shima, K. and Teixeira Da Silva, J.A. 2006. The World floriculture industry: dynamics of production and markets. In: Floriculture, Ornamental and Plant Biotechnology, Advances and Topical Issues. Volume 4. (Teixeira da Silva, J. A., Ed.). Global Science Books, London, UK. 336-347.

\section{How to cite this article:}

Bhandari, N.S. and Aswath, C. 2018. Standardization of an Effective Protocol for in vitro Culture of Lilium longiflorum Thunb cv. Pavia. Int.J.Curr.Microbiol.App.Sci. 7(04): 11831190. doi: https://doi.org/10.20546/ijcmas.2018.704.131 